\title{
THE EFFECT OF POTASSIUM CHLORIDE ON HYPONATREMIA ${ }^{1}$
}

\author{
By JOHN H. LARAGH ${ }^{2}$ \\ (From the Department of Medicine, College of Physicians and Surgeons, Columbia University; \\ and the Presbyterian Hospital in the City of New York)
}

(Submitted for publication August 31, 1953; accepted February 10, 1954)

In cardiac edema as well as in various other states characterized by excessive retention of fluid there is observed frequently an abnormally low concentration of sodium in the serum and extracellular fluid $(1,2)$. Rigorous sodium restriction, mercurial diuretics, and cation exchange resins may exaggerate or produce this tendency to hypotonicity. Sodium administration often enhances accumulation of fluid, without increasing its tonicity, and hypertonic sodium chloride, though effective at times, may be neither beneficial nor safe (3).

Because of the shortcomings of these various therapies and because hyponatremia per se may play a role in the production of adverse symptoms, it seemed desirable to search for another diuretic agent which might promote the loss of excessive body water without aggravating disturbances in sodium metabolism. It was decided, therefore, to observe the effects of potassium salt in hyponatremia, not only because of its possible action as a diuretic agent but also because of its relation to sodium metabolism.

Potassium salts have long been considered a useful diuretic agent. "Salt of niter" (potassium nitrate) was recommended for the treatment of dropsy in 1679 by Thomas Willis (4). In 1920, Magnus-Levy (5) and Blum (6) showed that potassium chloride could be administered safely by mouth in relatively large doses in various edematous states and that it often produced a diuresis. Similar results have been obtained by others (7-9). Potassium salts have produced diuresis without excessive loss of sodium, acting apparently through suppression of renal tubular secretion of hydrogen ions (10) and possibly as a result of osmotic activity of electrolytes of tubular urine.

In addition to the renal effects of potassium salts, it was thought possible that their adminis-

1 This work has been aided by a grant from the National Heart Institute (USPHS).

2 Research Fellow, New York Heart Association. tration might favorably influence disturbances in sodium metabolism manifested by pathologic distribution of sodium and potassium within the body. Two recent studies have served to emphasize this important relationship between sodium and potassium. In vivo, with potassium depletion there is a movement of sodium ions into cells and an associated extracellular alkalosis. This intracellular sodium can then be mobilized by potassium administration (11). In vitro it has been shown that potassium transport is dependent upon energy of aerobic oxidation. If the cell is injured or metabolically inhibited potassium fails to accumulate and is replaced by an influx of sodium and water (12).

Accordingly, potassium chloride $(\mathrm{KCl})$ was given to an edematous, hyponatremic cardiac patient with the hope of effecting water diuresis. The procedure produced a reduced urine volume. Moreover, a striking increase in the serum sodium was observed at a time when there was no change in the external balance of sodium. This phenomenon seemed of sufficient interest to warrant further study. The observed and derived transfers of sodium and potassium were, therefore, studied by the balance method following $\mathrm{KCl}$ administration in six patients with and without edema.

\section{METHOD}

Patient selection. Six patients, ranging in age from 22 to 65 years, were studied on the medical or metabolic wards of the Presbyterian Hospital. The criteria for selection included hyponatremia (serum sodium less than $126 \mathrm{mEq}$. per liter) and the absence of advanced renal disease (blood urea nitrogen less than $30 \mathrm{mg}$. per cent, except for one value of 39 on one occasion in a single patient). One subject each with the following conditions was studied: rheumatic heart disease with edema, Laënnec's cirrhosis with ascites, tetralogy of Fallot with edema, tuberculous meningitis, and unclassified collagen disease with accelerated hypertension and proteinuria. The latter two patients had no detectable edema. In addition, one patient was studied with edema due to cor pulmonale but without significant hyponatremia. 


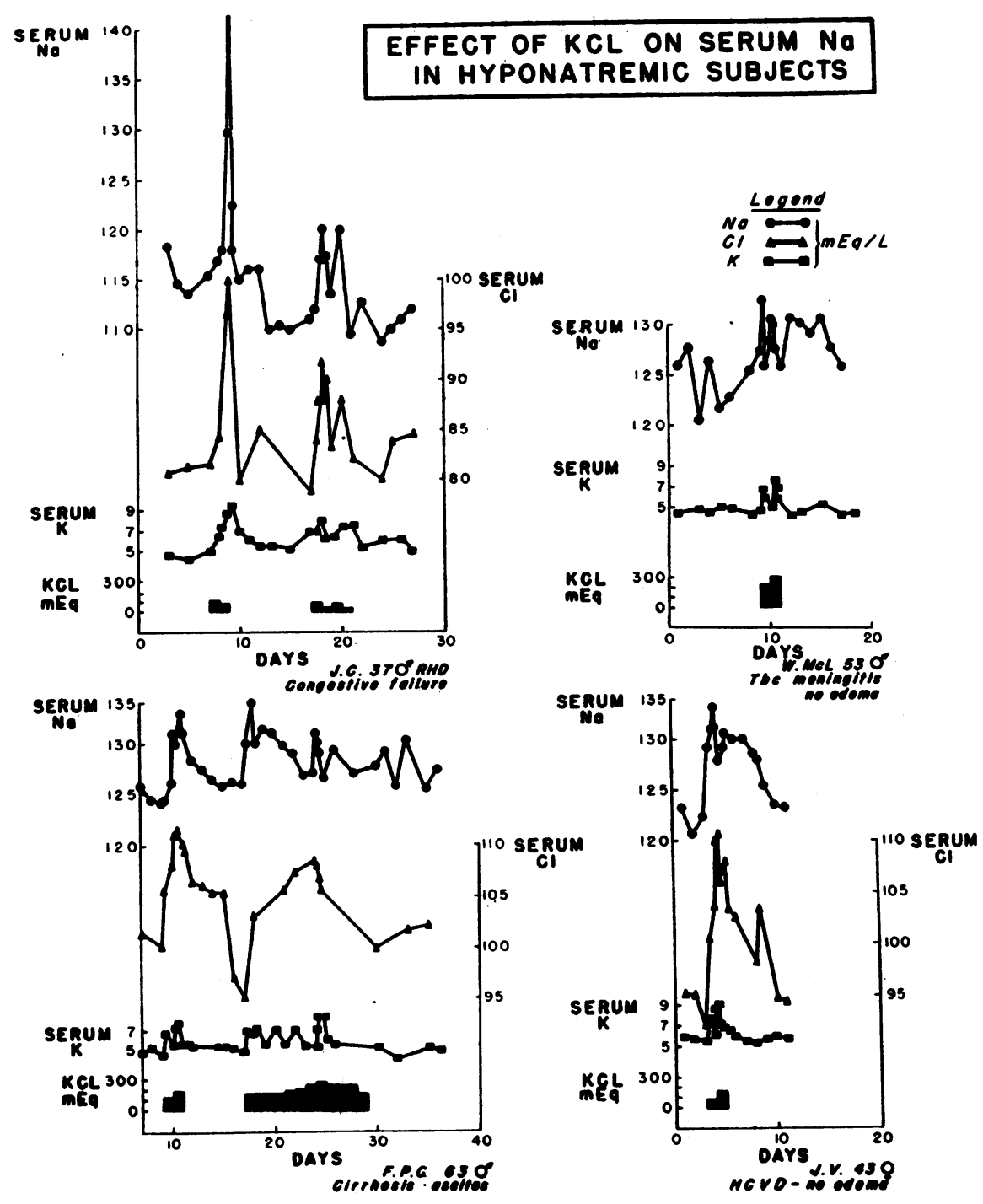

FIGURE 1

Procedure. Four of the patients were transferred to the metabolism ward, where they were treated throughout the study with bed-rest and sedatives. No diuretic was given, but digitalis therapy was maintained in constant dosage. Weights were measured in the fasting state. The patients were maintained on constant amounts of distilled water and on a constant weighed, low sodium diet, the nature and quantity of which were selected by the patient during a preliminary period.

The balance studies were divided into periods of from three to six days during which the daily diet was kept constant by weight from identical food lots. Daily diets were analyzed in duplicate periodically for sodium and potassium content and the composition of any vomitus or uneaten residue was determined. Urine was collected during consecutive 24 hour periods ( 8 a.m. to 8 a.m.), measured for volume, and analyzed daily for sodium, potassium, and chloride. All stools were pooled for each period and analyzed similarly.

Venous blood was drawn without the application of a tourniquet when possible and was delivered under oil for $\mathrm{CO}_{2}$ determinations. Blood specimens were usually obtained daily in control periods and as often as six times per day during periods of $\mathrm{KCl}$ administration. Blood was allowed to clot for 45 minutes and then separated. Serum was then analyzed for sodium, potassium, chloride, $\mathrm{CO}_{2}$, urea, and total protein. In two patients, balance studies were not done and serum electrolytes only were observed. A 20 per cent solution of $\mathrm{KCl}$ was administered orally in amounts ranging from 54 to 295 mEq. (4 to 22 grams) per day and given in divided doses, three to four times a day. Serum potassium levels were followed closely after each dose and serial electrocardiograms were taken. 
Analytical methods. Sodium and potassium were determined with a barrier layer photo cell flame photometer (lithium internal standard) having an accuracy of \pm 1 per cent (13). Chloride was determined by the method of Schales and Schales (14) or by a modified Volhard titration. Serum carbon dioxide content was measured with the Van Slyke manometric apparatus. Serum urea nitrogen was determined by direct nesslerization according to the method of Gentzkow (15). The hematocrit was determined by the Wintrobe method, and serum protein by a specific gravity gradient tube by Lowry's modification of the micro-method of Linderstr $\phi \mathrm{m}$-Lang (16). The exchangeable body sodium (24-hour) as well as the 4-hour sodium space was determined employing $\mathrm{Na}^{2}$ after the method of Forbes and Perley (17).

Analyses of diet and stool were made in triplicate. These specimens were homogenized and made up to a known volume with distilled water. Aliquots for sodium and potassium determinations were digested until clear with equal volumes of concentrated nitric acid on an electric hot plate, filtered, and made to volume with lithium for analysis by flame photometer

Calculations. In the balance studies the total balance for sodium and potassium represents the difference be- tween intake (calculated as the sum of diet and medications) and output (the sum of losses in the urine and stool). Because of the nature of the observed changes, no corrections were made for electrolytes lost by bloodletting, and the potassium balance was not corrected for changes in nitrogen balance. No studies were carried out in the summer months.

In considering possible changes in the distribution of sodium and potassium between the extra- and intracellular compartments, the intracellular balance was calculated as the difference between the measured external balance and an estimate of the extracellular space of 20 per cent of body weight. This latter calculation is not essential to these studies but is used as a means of depicting the type and direction of some of the changes. Since most of the patients were edematous, the assumed extracellular space is probably considerably less than the true value, and the postulated shifts of electrolyte are therefore estimated conservatively. For example, in two of the patients, J. C. and F. P. C., the four-hour $\mathrm{Na}^{24}$ space was found to be 36 and 39 per cent of body weight, respectively. However, essentially the same conclusions resulted from calculations based on larger initial extracellular volumes.

TABLE I

Dosage schedules of $\mathrm{KCl}$ and observed effects on serum potassium

\begin{tabular}{|c|c|c|c|c|c|}
\hline \multirow[b]{2}{*}{$\begin{array}{c}\text { Pt.* } \\
\text { Date }\end{array}$} & \multirow{2}{*}{$\begin{array}{l}\text { Total } \\
\text { dose of } \\
\mathrm{KCl}\end{array}$} & \multirow{2}{*}{$\begin{array}{l}\text { Duration } \\
\text { of the } \\
\text { dosage } \\
\text { period }\end{array}$} & \multicolumn{2}{|c|}{ Serum potassium } & \multirow{2}{*}{$\begin{array}{l}\text { Time for } \\
\text { return to } \\
\text { control } \\
\text { level } \\
\text { (after last } \\
\text { dose) }\end{array}$} \\
\hline & & & Controlt & $\underset{\text { peak }}{\text { Observed }}$ & \\
\hline J. C. & $\begin{array}{c}m E q . \\
187\end{array}$ & $\begin{array}{c}\text { days } \\
2\end{array}$ & $\begin{array}{c}m E q . / L \\
4.5\end{array}$ & $\begin{array}{c}m E q . / L \\
9.5\end{array}$ & $\begin{array}{l}\text { hrs. } \\
120\end{array}$ \\
\hline J. ${ }_{3 / 18}^{C}$ & 107 & 1.5 & 5.7 & 7.9 & 72 \\
\hline F. P. C. & 322 & 2 & 4.7 & 7.5 & 26 \\
\hline F. P. C. & 322 & 2 & 5.1 & 7.1 & 24 \\
\hline F.S. & 121 & 1.5 & 4.5 & 5.7 & 48 \\
\hline A. M. & 563 & 5 & 4.7 & 6.5 & $>60$ \\
\hline $\begin{array}{l}\text { A. M. } \\
1 / 20\end{array}$ & 161 & 2 & 5.0 & 5.6 & 48 \\
\hline J. V. & 241 & 1.5 & 5.7 & 9.2 & 40 \\
\hline$\underset{5 / 5}{W_{i}}$ & 523 & 2 & 4.5 & 7.3 & 18 \\
\hline
\end{tabular}

* All patients were studied while on constant low sodium diet containing from 7 to $15 \mathrm{mEq}$. of sodium except for Pt. A. M. who was studied while on constant low sodium and again $(1 / 20)$ on constant higher intake of $68 \mathrm{mEq}$. of
sodium daily.

$\uparrow$ Controls $=$ average of three determinations. 


\section{RESULTS}

The results of these studies are summarized in Figure 1 and Tables I, II, and III. In Table IV more complete metabolic data from one patient are presented.

The first patient (J. C., Figure 1 and Tables I, II, and III) was a 37-year-old man with long standing rheumatic heart disease. $\mathrm{He}$ had had atrial fibrillation for at least five years and, despite vigorous treatment including injections of mercuhydrin two or three times weekly, had been in chronic, right-sided failure for two years. This patient had the following serum electrolyte values: sodium $128 \mathrm{mEq}$ per L., potassium $5.3 \mathrm{mEq}$. per L., chloride $96 \mathrm{mEq}$. per L., and $\mathrm{CO}_{2}$ content 29 mm. per L. After eight days of Carbo-Resin (Lilly), $60 \mathrm{Gm}$. daily, there was a further gain in weight, the patient became weak and fatigued, and the serum sodium fell to $114 \mathrm{mEq}$. per $\mathrm{L}$. and the chloride to $81 \mathrm{mEq}$.per $\mathrm{L}$. The serum $\mathrm{CO}_{2}$ content did not change significantly. These changes could not be accounted for by the small amounts of sodium and chloride excreted and probably represented, therefore, either a relative hemodilution, or a transfer of sodium chloride into the cellular phase.

On the twelfth day of the study resins were discontinued. Thereafter, on days 14 and 15, 107 $\mathrm{mEq}$. and then $80 \mathrm{mEq}$. of $\mathrm{KCl}$ were given by mouth. A delayed and relatively prolonged hyperkalemia was noted, with a transient rise in the serum sodium to a peak of $143 \mathrm{mEq}$. per L. (an increase of $27 \mathrm{mEq}$.). This rise was noted 25 hours after the last dose of $\mathrm{KCl}$ chloride. Concomitantly, serum chloride rose to a peak of $103 \mathrm{mEq}$. per L. The patient also reverted to regular sinus rhythm

TABLE II

External balance of electrolyte and maximal changes in serum sodium after $\mathrm{KCl}$ administration *

\begin{tabular}{|c|c|c|c|c|c|c|c|c|c|c|c|c|}
\hline \multirow{3}{*}{$\begin{array}{r}\text { Pt. } \dagger \\
\text { Date }\end{array}$} & \multirow{3}{*}{$\begin{array}{l}\text { Maximal } \\
\text { changes in } \\
\text { serum Na }\end{array}$} & \multicolumn{2}{|c|}{$\begin{array}{c}\text { Time of maximal } \\
\text { serum Na }\end{array}$} & \multirow{3}{*}{$\begin{array}{c}\text { Dura- } \\
\text { tion of } \\
\text { the con- } \\
\text { current } \\
\text { balance } \\
\text { study }\end{array}$} & \multirow{2}{*}{\multicolumn{3}{|c|}{$\begin{array}{c}\text { External balancesł for the } \\
\text { entire period }\end{array}$}} & \multirow{3}{*}{$\begin{array}{l}\text { Body } \\
\text { wgt. }\end{array}$} & \multicolumn{4}{|c|}{$\begin{array}{c}\text { Calculated mEq. shift } \\
\text { intra and extracellular balances }\end{array}$} \\
\hline & & \multirow{2}{*}{$\begin{array}{l}\text { After } \\
\text { start }\end{array}$} & \multirow{2}{*}{$\begin{array}{l}\text { After } \\
\text { last } \\
\text { dose } \\
\end{array}$} & & & & & & \multicolumn{2}{|c|}{ Sodium } & \multicolumn{2}{|c|}{ Potassium } \\
\hline & & & & & $\mathrm{Na}$ & $\mathbf{K}$ & $\mathrm{Cl}$ & & ECW & ICW & ECW & $\mathrm{ICW}$ \\
\hline $\mathrm{J} \cdot \mathrm{C}$. & $\begin{array}{c}m E q . / L \\
+27\end{array}$ & $56^{\text {hou }}$ & 25 & $\begin{array}{c}\text { hours } \\
72\end{array}$ & $\begin{array}{l}m E q . \\
+23\end{array}$ & $\begin{array}{l}m E q . \\
+282\end{array}$ & $\begin{array}{c}m E q . \\
+212\end{array}$ & $\begin{array}{c}K g \\
57\end{array}$ & +324 & -301 & +45 & +237 \\
\hline J. C. & +9 & 26 & 2 & 48 & +1.2 & +101 & +92 & & +108 & -107 & +6 & +95 \\
\hline$\underset{4 / 9}{\text { F.P. C. }}$ & +9 & 48 & 12 & 48 & +27 & +104 & +206 & 86 & +156 & -129 & +20 & +84 \\
\hline$\underset{4 / 17}{\text { F. P. C. }}$ & +9 & 26 & 1 & 48 & +28 & +101 & +166 & & +156 & -128 & +20 & +81 \\
\hline F. S. & +5 & 24 & 12 & 24 & +4 & +76 & +92 & 56.5 & +60 & -56 & +12 & +64 \\
\hline$\underset{1 / 6}{\text { A. M. }}$ & +2.5 & & 12 & 120 & +0.2 & +183 & +116 & 58.1 & +30 & -30 & +15 & +168 \\
\hline A. M. & +2.5 & 24 & 12 & 24 & +14 & +40 & +45 & & +30 & -16 & +9 & +31 \\
\hline J. V. & +12 & 30 & 1 & & & & & 43.5 & +117 & & +30 & \\
\hline W. McL. & +7 & 6 & 1 & & & & & 70 & +98 & & +33 & \\
\hline
\end{tabular}

* This table presents data indicating that large internal shifts of sodium ion have occurred after $\mathrm{KCl}$ which cannot be accounted for by change in overall sodium balance. Calculations of intra and extracellular balance are presented to depict the type and direction of internal change of electrolyte. An error in these estimated changes is the fact that maximal serum changes of ten occurred within nearest $24 \mathrm{hr}$. balance periods and of ten were subsiding at the time the nearest concurrent balance period collections were closed.

$\dagger$ The first two patients were each studied on two different occasions. All were on constant low sodium diets excepting Pt. A. M. who on the second study was given a constant but higher sodium intake.

$\ddagger$ External balance $=$ sum of intake minus output (urine and stool) for the stated period during which $\mathrm{KCl}$ was being administered. No corrections have been made for insensible loss.

8 Calculated balances are based on the assumption that ECW is about 20 per cent of body weight (see Text). The $\mathrm{ECW}$ balance is thus calculated as maximal increase in $\mathrm{Na}$ and $\mathrm{K}$, respectively, times the assumed ECW volume. The ICW balance represents the difference between estimated ECW balance and observed external balance. 
TABLE III

The effect of $\mathrm{KCl}$ administration on body weight and on the urinary excretion of sodium and water

\begin{tabular}{|c|c|c|c|c|c|c|}
\hline \multirow[b]{2}{*}{$\begin{array}{c}\text { Pt. } \\
\text { Date }\end{array}$} & \multicolumn{2}{|c|}{ Body weight } & \multicolumn{2}{|c|}{$24 \mathrm{hr}$. urine volume } & \multicolumn{2}{|c|}{$24 \mathrm{hr}$. total urine sodium } \\
\hline & Control* & $\begin{array}{c}\text { After } \\
\mathbf{K C l}\end{array}$ & Control* & $\underset{\mathbf{K C l}}{\text { During }}$ & Control* & $\underset{\mathrm{KCl}}{\text { During }}$ \\
\hline $\mathrm{J} \cdot \underset{3 / 7}{\mathrm{C}}$ & 56.9 & 57.4 & 780 & 580 & 0.9 & 1.3 \\
\hline$\underset{3 / 18}{\mathrm{C} .}$ & 57.6 & 57.0 & 970 & 455 & 1.1 & 2.3 \\
\hline F. P. C. & 86.4 & 86.7 & 1250 & 1485 & 0.2 & 0.9 \\
\hline F.S. & 56.1 & 55.9 & 700 & 375 & 0.9 & 1.4 \\
\hline A. ${ }_{1 / 6}^{M}$ & 58.1 & 57.6 & 1223 & 1145 & 16.9 & 17.0 \\
\hline$\underset{1 / 26}{\text { A. M. } \dagger}$ & 57.3 & 57.8 & 1155 & 1050 & 32.3 & 39.4 \\
\hline $\mathrm{J} \cdot \mathrm{V}_{4 / 14}$ & 42.8 & 43.9 & 1275 & 975 & 一 & 一 \\
\hline$\underset{5 / 5}{\text { W. Mc. }}$ & - & - & 1600 & 1550 & - & - \\
\hline
\end{tabular}

* Control is the average of 3 control day measurements. During $\mathrm{KCl}$ is the average daily excretion while on the drug. After $\mathrm{KCl}$ is the weight at the end of period of administration.

$\dagger$ A. M. was studied on a higher as well as low salt diet.

when the serum potassium reached $9.5 \mathrm{mEq}$. per $\mathrm{L}$. and remained in sinus rhythm for several months thereafter.

The large increase in the extracellular concentration of sodium which was noted in this patient as well as in others could, theoretically at least, be attributed to any of the following factors :

1. A positive overall sodium balance;

2. A decrease in the extracellular fluid volume without a commensurate change in the total amount of extracellular sodium;

3. A migration of sodium from the intra to the extracellular fluid space.

No additional sodium was administered and only minor alterations from control periods occurred in sodium excretion when $\mathrm{KCl}$ was given (Table III). These small changes in sodium balance following $\mathrm{KCl}$ administration could not possibly account for the observed fluctuations in serum levels of sodium. For example, in patient J. C., the maximal rise in serum sodium concentration of $27 \mathrm{mEq}$. per L. occurred at a time when both sodium intake and excretion were not significantly altered (Tables I, II, and III).
Evidence pertaining to possible changes in extracellular fluid volume may be summarized as follows. At the time when the peak change in serum sodium was noted, there was no significant change in weight, or increase in urine volume. Furthermore, in all cases changes in serum protein and hematocrit were minimal and revealed no consistent evidence of hemoconcentration. Changes in extracellular fluid volume were calculated by the method of Darrow (18) and these also failed to reveal any contraction of extracellular fluid space. Some examples of these calculations are given below. The possibility that the serum sodium level increased because of a contraction in the extracellular space may, therefore, be dismissed from further consideration and changes will be described assuming no significant changes in extracellular volume. A shift of sodium from the intra to the extracellular compartments is, therefore, perhaps demonstrated in this and subsequent patients by exclusion of above factors.

Assuming patient J. C. to have an extracellular volume of at least 12 liters and that the increase in serum sodium concentration represented a trans- 


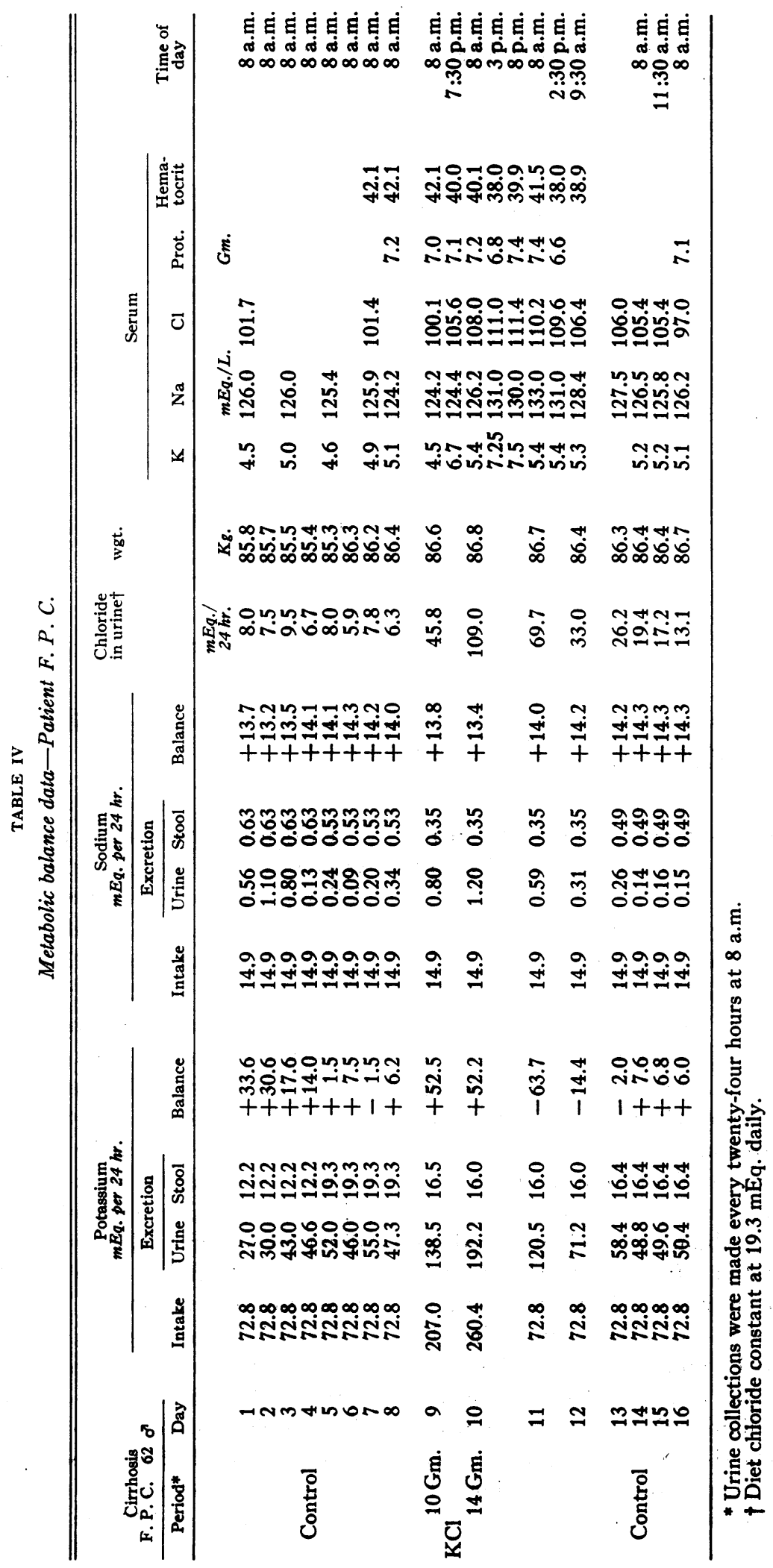


fer of sodium into the extracellular space, this alteration would represent a mobilization of 324 $\mathrm{mEq}$. of sodium. If this increase in extracellular sodium resulted from cellular transfer, then the question of whether it exchanged with potassium ion may be raised. Only $312 \mathrm{mEq}$. of potassium were administered, including that of the diet, and at the time of maximal change in serum sodium some 20 to $30 \mathrm{mEq}$. had been excreted. The peak serum level of $9.5 \mathrm{mEq}$. per L. might account for another $45 \mathrm{mEq}$. Some $237 \mathrm{mEq}$. of potassium, therefore, would be available to enter cells and exchange with sodium.

The administration of $\mathrm{KCl}$ was repeated in the same patient. When $107 \mathrm{mEq}$. of $\mathrm{KCl}$ were added to the diet the serum sodium rose by $9 \mathrm{mEq}$. per L., representing an apparent increase in total extracellular sodium of $108 \mathrm{mEq}$. At the time of maximal rise in sodium the serum potassium was increased by $0.5 \mathrm{mEq}$. per L. and, at this time, roughly $20 \mathrm{mEq}$. of potassium had been excreted. Including the diet, this could leave an excess of about $95 \mathrm{mEq}$. of potassium, either in cells or intestine, which was associated with the rise in serum sodium. By these estimations it appears again that the increase in extracellular sodium could perhaps be accounted for by an exchange with potassium. Serum protein concentration and hematocrit revealed no changes to suggest transfer of water from the extracellular fluid which might also have been a factor in the rise in extracellular sodium. Finally, this patient was given $\mathrm{NH}_{4} \mathrm{Cl}$ in an amount equivalent to the $\mathrm{KCl}$ previously administered, and no changes in serum sodium and potassium were observed, suggesting that potassium ion is necessary for the production of the observed phenomenon.

Data for a second patient, F. P. C., with decompensated Laënnec's cirrhosis, are presented in Figure 1 and Tables I through IV. While on a constant low sodium diet $\mathrm{KCl}$ was administered (322 mEq. in two days) and an increase in the serum sodium concentration of $9 \mathrm{mEq}$. per $\mathrm{L}$. was observed. This massively edematous man had an assumed extracellular volume of 17.3 liters. Ceteris paribus, the change in the serum sodium concentration would represent the mobilization of at least $156 \mathrm{mEq}$. of sodium into the extracellular space. This rise occurred at a time when more than $100 \mathrm{mEq}$. of administered potassium remained within the body, largely within cells. There was no significant change in serum protein concentration.

Balances between the intra and extracellular compartments were calculated by the method of Darrow (18) assuming an obligatory extracellular position for chloride and also assuming an extracellular fluid volume of 20 per cent of body weight at the start of administration of $\mathrm{KCl}$. The serum sodium rose from 124 to $133 \mathrm{mEq}$. per L. during the 48-hour period of $\mathrm{KCl}$ administration. With an assumed initial extracellular space of $\mathbf{1 7 . 3}$ L. this space was calculated to be $17.6 \mathrm{~L}$. at the end of the 48-hour period. On the basis of these values and the changes in serum sodium concentration, the calculated distribution of sodium was: external balance $+26 \mathrm{mEq}$; ; extracellular balance $+190 \mathrm{mEq}$. ; and intracellular balance $-164 \mathrm{mEq}$. The comparable values for potassium were: external balance $+104 \mathrm{mEq}$.; extracellular balance $+16 \mathrm{mEq}$.; and intracellular balance $+88 \mathrm{mEq}$. With this type of calculation, approximate estimates for the first patient, J. C. also indicate that the rise in serum sodium of $27 \mathrm{mEq}$. per L. represented the migration of about $300 \mathrm{mEq}$. of sodium from the intracellular space with a positive intracellular $\mathrm{K}$ balance of about $237 \mathrm{mEq}$. Within the limits of accuracy of these calculations, the data for all patients indicate that the rise in serum sodium can be attributed to a cellular exchange for potassium.

The $\mathrm{KCl}$ was administered over a twelve-day period in progressively increasing dosage to a maximum of $295 \mathrm{mEq}$. daily (patient F. P. C.). Similar changes in serum sodium were observed, again without related variation in serum protein. Of note is the recurrent tendency for the serum sodium to return to lower levels shortly after each increase in $\mathrm{KCl}$ dosage.

In Figure 1 and Tables I, II, and III data are presented from a similar study, performed without balances, on patient J. V. This patient was a 43year-old woman with a two-year history of accelerated hypertensive disease. She had a serum protein concentration of $5.4 \mathrm{Gm}$. per cent. Her disease process was considered by some to represent a diffuse collagen disease. There was no detectable edema. On a moderately low sodium diet the serum sodium was found to be consistently in the 120 to $123 \mathrm{mEq}$. per L. range. There also was 
observed a consistently elevated serum potassium in the range of $6.0 \mathrm{mEq}$. per L. She was given 240 $\mathrm{mEq}$. of $\mathrm{KCl}$ orally in two days. The serum sodium concentration increased $12 \mathrm{mEq}$. per $\mathrm{L}$. Calculating as previously, the change could represent an extracellular increment of at least 117 $\mathrm{mEq}$. of sodium. The serum potassium reached a peak of $9.1 \mathrm{mEq}$. per L. No accurate estimate can be made of the amount of potassium within cells, but necessarily the balance is strongly positive and might approach $150 \mathrm{mEq}$. In this patient the rise in serum sodium concentration was more sustained. Serum proteins, in contrast to the first two subjects, increased slightly with the rise in serum sodium ( 5.4 to $5.6 \mathrm{Gm}$. per cent), suggesting the possibility of some degree of hemoconcentration and water shift into cells.

Similar observations were made on a febrile man with tuberculous meningitis (W. McL.). This patient's hyponatremia had previously been treated vigorously with sodium by mouth and hypertonic saline by vein without striking benefit. Control electrolyte values were more variable (Figure 1) but the change in serum sodium after $228 \mathrm{mEq}$. of $\mathrm{KCl}$ in one day appeared to be significant ( $+7 \mathrm{mEq}$. per L.) and, moreover, was relatively sustained. Serum proteins increased from 6.9 to $7.1 \mathrm{Gm}$. per cent, suggesting a slight reduction in extracellular fluid volume. This subject differs from the others in that considerably more potassium was given to produce a smaller rise in serum sodium concentration. Renal function was normal.

F. S. (Tables I, II, and III) was a 29-year-old man with Tetrology of Fallot and edema. Before treatment serum electrolyte values were: sodium $111 \mathrm{mEq}$. per L., potassium $4.0 \mathrm{mEq}$. per L., chloride $79 \mathrm{mEq}$. per L., $\mathrm{CO}_{2} 25 \mathrm{~mm}$. per L. Following administration of $94 \mathrm{mEq}$. of $\mathrm{KCl}$ in one day the serum rose to $117 \mathrm{mEq}$. per $\mathrm{L}$. without change in weight and, again, urine volume was reduced. Assuming an extracellular volume of only 12 liters, the rise in sodium could represent a mobilization of 60 to $70 \mathrm{mEq}$. of sodium into the extracellular fluid. At the time of the change in serum sodium this patient retained about $64 \mathrm{mEq}$. of potassium outside of the extracellular space. In contrast to all of the other edematous patients, the rise in serum sodium produced in this man was followed by a diuresis. Fifteen days later serum sodium was $130 \mathrm{mEq}$. per L. and three days thereafter $140 \mathrm{mEq}$. per $\mathrm{L}$.

Subject A. M., Tables I, II, and III, was a 47year-old patient with a more normal serum sodium concentration. This woman, with cor pulmonale, was massively edematous and her serum sodium concentrations varied from 135 to $138 \mathrm{mEq}$. per L. While on a low sodium diet she was given relatively small, gradually increasing doses of $\mathrm{KCl}$ over a five-day period; the total dose given was $563 \mathrm{mEq}$. of $\mathrm{KCl}$. A diuresis was not induced. The serum sodium rose to $140 \mathrm{mEq}$. per L.-a small change perhaps not exceeding the error of the method. After a control period on a higher sodium intake (67.5 mEq. daily) $\mathrm{KCl}$ was given again. Even with this higher sodium intake no diuresis was observed after potassium administration, nor did the diet with its higher salt content affect the serum sodium. There was, however, another slight increase in serum sodium from 137 $\mathrm{mEq}$. per L. to $140 \mathrm{mEq}$. per L. when potassium chloride was added.

The changes in serum chloride concentration in these patients, in general paralleled the changes in serum sodium. The $\mathrm{CO}_{2}$ content of the blood showed a general tendency to fall slightly during $\mathrm{KCl}$ administration.

The three hyponatremic edematous subjects were all excreting less than $1 \mathrm{mEq}$. of sodium a day while on constant low sodium diets (Table III). When $\mathrm{KCl}$ was given to these patients there was no significant change in sodium excretion despite simultaneous increase in the serum sodium concentration. Moreover, potassium did not produce significant changes in sodium excretion in an edematous cardiac patient (A. M.) who had a higher serum sodium level. This was also true after dietary sodium had been increased.

The twenty-four hour exchangeable sodium $\left(\mathrm{Na}^{24}\right)$ mass was measured in the first two patients before and after $\mathrm{KCl}$. In patient J. C., the exchangeable sodium which was measured on two occasions before and again twice after $\mathrm{KCl}$ revealed an increase of $300 \mathrm{mEq}$. in the exchangeable sodium after $\mathrm{KCl}$. These data are suggestive also of an increase in sodium concentration as a result of an increase in the total exchangeable pool secondary to mobilization of previously "bound" sodium by exchange with potassium. In contrast, 
however, in patient F. P. C. no significant change was observed.

\section{DISCUSSION}

The present study illustrates that in hyponatremic patients, a significant rise in serum sodium concentration may follow the oral administration of potassium chloride. In the absence of a significant change in overall sodium balance the observed phenomenon must represent either (a) a loss of water from the extracellular fluid, or (b) a release of sodium into the extracellular fluid, or (c) a combination of the two.

With reference to the first possibility, no definite or consistent evidence of hemoconcentration was obtained. However, small but significant fluid shifts may have been masked by the known diurnal and postural variations in serum protein concentrations (19). When the distribution between intra- and extracellular phases is calculated by Darrow's method, no significant changes in the chloride space were observed. The positive balance of chloride was associated with a rise in chloride concentration. In addition, if water moved from the extracellular fluid to the cells along with potassium, this should have produced increased osmolarity of the extracellular space which of necessity, would give rise to osmotic inequality. Thus, if the osmotic pressure is raised outside of cells, it ought to be correspondingly increased inside.

With reference to the second possibility, i.e., the extracellular increment of sodium by redistribution from cells or other depots, only circumstantial evidence has been obtained, by exclusion of other likely possibilities. It has been established that under various circumstances sodium may replace potassium in cells. Thus, sodium can replace intracellular potassium after administration of desoxycorticosterone (20), in rats raised on a low potassium diet (21), in hypokalemic alkalosis (22), and in infantile diarrhea (18). Moreover, other investigators (23), studying familial periodic paralysis, have obtained evidence in one case of reciprocal sodium and potassium changes. That a sodium reservoir exists is suggested by the more recent work of Bergstrom (24) in rats, which indicates that, within 48 hours following base depletion, bone can release considerable sodium and potassium. In addition, Levitt, Turner, and Sweet (25) report that, during venous obstruction in man, a rise in the inulin space may be accompanied by an increase in extracellular sodium chloride. These analogies also make the supposition that potassium has exchanged with sodium the more likely explanation of the results observed in the present study.

Abnormalities of the intracellular fluid in the disease states under study have be demonstrated. Analyses of biopsy specimens of skeletal muscle of hyponatremic patients in congestive heart failure suggest that there may be more sodium and less potassium than normal within cells $(3,26)$. However, the reported data are not altogether consistent (27). Other investigators $(1,28-30)$ have reported retention of potassium in excess of nitrogen in patients recovering from congestive heart failure. Elkinton, Squires, and Bluemle (31), have concluded on the basis of their data that in cardiac failure intracellular abnormalities consist of potassium depletion, with associated increase of osmolarity of solutes present in the cells, and cellular overhydration. Fox, Friedberg, and White (32) had previously reported that the administration of potassium and sodium salts to patients in heart failure resulted in a positive potassium balance. These data suggest, but do not prove, that in heart failure sodium may pass through the cell membrane and potassium may leave the cell. Moreover, in experimental hypertension $(33,34)$ and in human hypertensive disease (35) evidence has been reported suggesting increased intracellular sodium content. In tuberculous meningitis, Harrison, Finberg, and Fleishman (36) found an increased sodium and decreased potassium content of muscle.

The data presented here afford evidence that, in the patients of this study, a large fraction of the administered potassium is stored, at least temporarily, beyond the confines of the extracellular fluid. These observations are in agreement with previously reported data. According to the studies of Winkler, Hoff, and Smith (37), the increase in concentration of serum potassium after an ingested or injected dose is only one-third as high as would be expected were its distribution purely extracellular-about two-thirds of the absorbed potassium leaves the extracellular fluid. Other investigators (38) have subsequently administered $\mathrm{K}^{42}$ to animals and shown that it is rapidly taken 
up, first by the viscera, probably with an anion, and then slowly released to muscles and other tissues ( 50 to 60 per cent of body potassium exchanges in 12 hours). The tissues of the body therefore seem capable of storing, at least temporarily, large amounts of potassium; i.e., as Winkler has stated the body has a buffer capacity with respect to potassium. The transport of potassium into cells is conditioned evidently by metabolic activity (39); when it enters cells osmotic equality may be maintained by entrance of water, by exit of sodium, by change in activity of cell cations and anions.

In contrast to the large amounts of potassium ion tolerated by normal subjects $(9,10,40)$ and even by patients with renal insufficiency (37), the patients of this study developed significant hyperkalemia with relatively small doses of potassium chloride and in some the return to normal serum potassium levels appeared to be delayed (Table I). Brown, Tanner, and Hecht (40) have reported on similar observations in a group of cardiac patients, and point out that this finding is of particular interest since it has been stated that it is difficult, if not impossible, to produce potassium poisoning except in patients with renal failure, shock, or adrenal insufficiency (22). Indeed, Winkler, Hoff and Smith (37) were unable to produce fatal potassium poisoning in normal dogs unless they ligated the ureters.

The diminished capacity of edematous (41) and hyponatremic subjects to excrete electrolyte may be in part responsible for the magnitude of the observed phenomena. When $\mathrm{KCl}$ is given, this represents the addition to the body of primarily obligatory extracellular anions with a largely intracellular cation. The observed rise in serum sodium could be attributed to decreased capacity to excrete potassium itself, and then subsequent to exchange of this potassium for intracellular sodium, the continued inability to excrete sodium, chloride, or bicarbonate. The fall in bicarbonate in all of these patients after addition of large amounts of chloride was always small and wholly inadequate to compensate for the chloride increase.

The sensitivity to potassium of the group reported here could, therefore, be the result of a renal insufficiency. However, only one of the patients had a primary renal disease and, moreover, patients with advanced renal disease often show no elevation of serum potassium even when the intake of potassium is high. This sensitivity, as a second possibility, may represent deficient capacity of body tissues to store potassium, and may also be specifically related to the concentration of, or absolute quantity of sodium in the body. This would perhaps be analogous to the tendency to hyperkalemia and potassium sensitivity observed in adrenal insufficiency. A preliminary injection of $\mathrm{NaCl}$ in animals will protect them from lethal doses of potassium (42), but this may be the result of specific cardiac protection.

The failure of potassium chloride to augment water or sodium excretion in the edematous patients studied occurred despite the fact that the low serum sodium levels often rose strikingly towards normal, suggesting perhaps that the concentration of serum sodium is not per se an important factor in sustaining sodium retention. This failure of diuresis of edematous hyponatremic subjects is in contrast to the response of normals and certain edematous states as reported by others.

\section{SUMMARY}

Potassium chloride was administered orally to hyponatremic patients with and without edema.

In these patients small to rather striking increases in the serum sodium concentration were observed without the addition of exogenous sodium.

The nature of the phenomenon is not wholly clarified but seems best explained by postulating a release of sodium from cells in exchange for potassium.

The estimated release of sodium ion was of the order of 60 to $300 \mathrm{mEq}$. The actual change was probably in excess of these values since the extracellular volume was estimated to be only 20 per cent of the body weight in patients often massively edematous.

In the edematous hyponatremic subject no significant change in renal excretion of sodium or water was observed, after potassium chloride administration, even when serum sodium levels were simultaneously raised towards normal. This occurred with both low and higher sodium intakes.

The hyponatremic patients studied seemed unable to metabolize potassium with normal facility and its administration is therefore not without 
hazard; when compared to normal subjects the hyperkalemia produced seemed to be more profound and more prolonged. Moreover, with the doses employed in this study potassium chloride did not exert a diuretic action.

\section{ACKNOWLEDGMENT}

The author is indebted to Dr. Gilbert H. Mudge and to Dr. George A. Perera for advice and assistance. He is also indebted to Misses Margaret Crymble and Ann Richards and Mrs. Laura Losin for technical assistance.

\section{REFERENCES}

1. Miller, G. E., Water and electrolyte metabolism in congestive heart failure. Circulation, 1951, 4, 270.

2. Squires, R. D., Singer, R. B., Moffitt, G. R., Jr., and Elkinton, J. R., The distribution of body fluids in congestive heart failure. II. Abnormalities in serum electrolyte concentration and in acid-base equilibrium. Circulation, 1951, 4, 697.

3. Stock, R. J., Mudge, G. H., and Nurnberg, M. J., Congestive heart failure. Variations in electrolyte metabolism with salt restrictions and mercurial diuretics. Circulation, 1951, 4, 54.

4. Willis, T., Pharmaceutice Rationalis, London, C. Dring, C. Harper, and J. Leigh.

5. Magnus-Levy, A., Alkalichloride und Alkalikarbonate bei Oedemen. Deutsche med. Wchnschr., 1920, 46, 594.

6. Blum, L., Recherches sur le role des sels alcalins dans la pathogénie des oedèmes: l'action diurétique du chlorure de potassium. Presse méd., 1920, 28, 685.

7. Basset, S. H., Elden, C. A., and McCann, W. S., The mineral exchanges of man: II. Effect of excess potassium and of calcium on two normal men and on an oedematous nephritic. J. Nutrition, 1932, 5, 1.

8. Keith, N. M., and Binger, M. W., Diuretic action of potassium salts. J.A.M.A., 1935, 105, 1584.

9. Loeb, R. F., Atchley, D. W., Richards, D. W., Jr., Benedict, E. M., and Driscoll, M. E., On the mechanism of nephrotic edema. J. Clin. Invest., 1932, 11, 621.

10. Berliner, R. W., Kennedy, T. J., Jr., and Orloff, J., Relationship between acidification of the urine and potassium metabolism; effect of carbonic anhydrase inhibition on potassium excretion. Am. J. Med., 1951, 11, 274.

11. Cooke, R. E., Segar, W. E., Cheek, D. B., Colville, F. E., and Darrow, D. C., The extrarenal correction of alkalosis associated with potassium deficiency. J. Clin. Invest., 1952, 31, 798.

12. Mudge, G. H., Potassium imbalance. Bull. New York Acad. Med., 1953, 29, 846.

13. Berry, J. W., Chappell, D. G., and Barnes, R. B., Improved method of flame photometry. Indust. \& Engin. Chem. (Anal. Ed.), 1946, 18, 19.
14. Schales, O., and Schales, S. S., A simple and accurate method for the determination of chloride in biological fluids. J. Biol. Chem., 1941, 140, 879.

15. Gentzkow, C. J., An accurate method for the determination of blood urea nitrogen by direct nesslerization. J. Biol. Chem., 1942, 143, 531.

16. Lowry, O. H., and Hastings, A. B., Histochemical changes associated with aging: I. Methods and calculations. J. Biol. Chem., 1942, 143, 257.

17. Forbes, G. B., and Perley, A. M., Determination of total body sodium in man with radiosodium ${ }^{24}$. J. Lab. \& Clin. Med., 1949, 34, 1599.

18. Darrow, D. C., The retention of electrolyte during recovery from severe dehydration due to diarrhea. J. Pediat., 1946, 28, 515.

19. Perera, G. A., and Berliner, R. W., The relation of postural hemodilution to paroxysmal dyspnea. J. Clin. Invest., 1943, 22, 25.

20. Loeb, R. F., The adrenal cortex and electrolyte behavior. Bull. New York Acad. Med., 1942, 18, 263.

21. Heppel, L. A., Electrolytes of muscle and liver in potassium depleted rats. Am. J. Physiol., 1939, 127, 385.

22. Darrow, D. C., Body-fluid physiology; the role of potassium in clinical disturbances of body water and electrolyte. New England J. Med., 1950, 242, 978 and 1014.

23. Danowski, T. S., Elkinton, J. R., Burrows, B. A., and Winkler, A. W., Exchanges of sodium and potassium in familial periodic paralysis. J. Clin. Invest., 1948, 27, 65 .

24. Bergstrom, W. H., Bone as a sodium and potassium reservoir. J. Clin. Invest., 1952, 31, 617.

25. Levitt, M. F., Turner, L. B., and Sweet, A. Y., The effect of experimental venous obstruction on salt and water distribution and excretion in man. $\mathrm{J}$. Clin. Invest., 1952, 31, 885.

26. Waterhouse, C., Keutmann, E. H., and Fenninger, L. D., Studies on the mechanism of edema formation in patients with low serum electrolytes. J. Clin. Invest., 1951, 30, 681.

27. Mokotoff, R., Ross, G., and Leiter, L., The electrolyte content of skeletal muscle in congestive heart failure; a comparison of results with inulin and chloride as reference standards for extracellular water. J. Clin. Invest., 1952, 31, 291.

28. Sinclair-Smith, B., Kattus, A. A., Genest, J., and Newman, E. V., The renal mechanism of electrolyte excretion and metabolic balances of electrolytes and nitrogen in congestive cardiac failure; the effects of exercise, rest, and aminophyllin. Bull. Johns Hopkins Hosp., 1949, 84, 369.

29. Iseri, L. T., Boyle, A. J., Rosow, W. A., Griffin, R., and Engstrom, F., Metabolic studies during treatment of severe congestive heart failure with 50 mgm. sodium diet. J. Clin. Invest., 1950, 29, 825.

30. Schwartz, W. B., and Wallace, W. M., Observations on electrolyte balance during mercurial diuresis in congestive heart failure. J. Clin. Invest., 1950, 29, 844. 
31. Elkinton, J. R., Squires, R. D., and Bluemle, L. W., Jr., The distribution of body fluids in congestive heart failure. IV. Exchanges in patients, refractory to mercurial diuretics, treated with sodium and potassium. Circulation, 1952, 5, 58.

32. Fox, C. L., Jr., Friedberg, C. K., and White, A. G., Electrolyte abnormalities in chronic congestive heart failure; effects of administration of potassium and sodium salts. J. Clin. Invest., 1949, 28, 781.

33. Sapirstein, L. A., and Greene, R., Total body sodium in hypertension in rat. Federation Proc., 1952, 11, 137.

34. Tobian, L., Jr., and Binion, J., Cation content of the aorta wall in renal and DCA hypertension. Circulation, 1952, 6, 469.

35. Tobian, L., Jr., and Binion, J. T., Tissue cations and water in arterial hypertension. Circulation, 1952, 5, 754.

36. Harrison, H. E., Finberg, L., and Fleishman, E., Disturbances of ionic equilibrium of intracellular and extracellular electrolytes in patients with tuberculous meningitis. J. Clin. Invest., 1952, 31, 300.

37. Winkler, A. W., Hoff, H. E., and Smith, P. K., The toxicity of orally administered potassium salts in renal insufficiency. J. Clin. Invest., 1941, 20, 119.

38. Fenn, W. O., Noonan, T. R., Mullins, L. J., and Haege, L., The exchange of radioactive potassium with body potassium. Am. J. Physiol., 1941, 135, 149.

39. Keith, N. M., Osterberg, A. E., and Burchell, H. B., Some effects of potassium salts in man. Ann. Int. Med., 1942, 16, 879.

40. Brown, H., Tanner, G. L., and Hecht, H. H., The effects of potassium salts in subjects with heart disease. J. Lab. \& Clin. Med., 1951, 37, 506.

41. Futcher, P. H., and Schroeder, H. A., Studies on congestive heart failure. II. Impaired renal excretion of sodium chloride. Am. J. M. Sc., 1942, 204, 52 .

42. Amberg, S., and Hemholz, H. F., The detoxifying action of sodium salts upon potassium salts on intravenous injection. J. Pharmacol. \& Exper. Therap., 1916, 8, 120. 